\title{
A szívizom metabolikus támogatása perkután koronária-intervenciót igénylö betegeknél
}

\author{
Kőszegi Zsolt \\ Debreceni Egyetem, Kardiológiai Intézet, Debrecen, Szabolcs-Szatmár-Bereg Megyei Kórházak és Egyetemi \\ Oktatókórház, Jósa András Oktatókórház, Invazív Kardiológiai Laboratórium, Nyíregyháza
}

Levelezési cím: Dr. Kőszegi Zsolt, 4032 Debrecen, Móricz Zs. krt. 22. E-mail: koszegi@dote.hu

A „mindenevő” szívizom a szubsztrát-környezettöl függően egyaránt képes hasznosítani szénhidrátot vagy zsírzsavakat, de az egységnyi oxigénfelhasználásra jutó energiatermelés nem azonos a különböző tápagyagok elégetése során. A glükózoxidáció során egy $\mathrm{O}_{2}$-molekulára átlagosan 5,2 adenozin-trifoszfát képződés esik, míg zsírsavoxidációval egy $\mathrm{O}_{2}$ csak 4,6 adenozin-trifoszfát termelődését eredményezi. Egyéb mechanizmusok bekapcsolódásán keresztül a glükózoxidáció végül $33 \%$-kal több energiát biztosít a szívizomnak, mint a zsírsavoxidáció.

Pozitronemissziós tomográfiás experimentális vizsgálatokkal igazolták, hogy a trimetazidin hemodinamikai hatás nélkül a szívizom anyagcseréjét a zsírsavoxidáció felöl az energetikailag hatékonyabb glükózoxidáció felé tereli. Klinikai tanulmányokban a trimetazidin a kardiovaszkuláris megbetegedések kezelésének új fejezetét nyitotta a krónikus iszkémiás szívbetegség kezelésére. Viszonylag nagy betegszámú vizsgálatok adatai állnak rendelkezésre a trimetazidin koszorúér-intervenció alatti citoprotektív hatásáról. A közvetlenül sejtszinten ható kedvező metabolikus hatás kivédheti az intervencióval járó átmeneti iszkémia okozta miokardiális károsodást, és csökkentheti a reperfúziós károsodás mértékét is.

Egy újabb tanulmány szerint a trimetazidin a gyógyszerkibocsátó stent beültetését követően a (neo)endothelre gyakorolt kedvező metabolikus hatása folytán csökkentheti a kóros mértékủ intimaproliferáció kialakulását. Ha ezek az előzetes eredmények további nagy esetszámú randomizált vizsgálatban is megerősítést nyernek, úgy várhatóan, az ISZB terápiás arzenáljában a stentimplantáció utáni esetekben még nagyobb szerepet kaphat a TMZ.

Kulcsszavak: szívizom-metabolizmus, perkután koronária-intervenció, trimetazidin

Myocardial metabolic support in patients with coronary disease treated by percutaneous interventions The "omnivorous" myocardium can utilize free fatty acids and glucose simultaneously in variable ratios according to substrate availability. During glucose oxidation one molecule $\mathrm{O}_{2}$ consumption produces 5.2 ATPs while fatty acid oxidation generate only $4.6 \mathrm{ATP} / \mathrm{O}_{2}$. Involving other mechanisms also, the cardiac efficiency can increase by $33 \%$ during glucose oxidation compared to the fatty acid consumption.

Experimental positron emission tomography studies showed that trimetazidine (TMZ) shifts the myocardial metabolism from the fatty acid oxidation to glucose oxidation being more efficient source of energy. In clinical investigations the TMZ proved to be a prominent agent in the metabolic treatment of coronary heart disease. The results of relatively large scale studies demonstrated the cytoprotective effect of TMZ in patients treated by percutaneous coronary interventions (PCI). The direct beneficial metabolic effect on cellular level can prevent the myocardium from the potential ischemic and reperfusion injury during the $\mathrm{PCl}$.

According to a recent study the TMZ reduces the pathological intimal hyperplasia after drug eluting stent implantation through its beneficial metabolic effect on the vascular cells. If these preliminary results will confirmed in large scale randomized trials then the TMZ can play even more role among the therapeutic actors of the coronary heart disease.

Keywords: myocardial metabolism, percutaneous coronary intervention, trimetazidine 


\section{Bevezetés}

A koszorúér-keringés adaptív tartalékai a nyugalmi miokardiális perfúziót még a koronáriák súlyos szükülete esetén is normál szinten tarthatják. Azonban krónikus iszkémiás szívbetegségben (ISZB) a koronária-rezerv nem tudja biztosítani a mindennapi igényeket, így kialakulnak a típusos anginás tünetek, amelyek mindig összefüggésbe hozhatók a szívizom-anyagcsere megváltozásával (1-3). Tehát, a koszorúér-betegség a szívizom vérellátási zavarát okozva miokardiális anyagcserezavart indukál.

\section{A szívizom normál és iszkémiás anyagcseréje}

Az egészséges szív legfőbb energiaforrása a zsírsavak oxidációja, amely energiaszükségletének 60-80\%-át fedezi, de a szénhidrátok elégetésével is biztosítható a szív munkája. Az adenozin-trifoszfát (ATP) a sejt energiaforgalmának valutájaként müködik, lebomlása fedezi a kontrakciók energiaszükségletét. Az ATP a mitokondriumokban szintetizálódik, az ehhez szükséges energia a glükóz, a laktát és a zsírsavak oxidációjából származik. A szívizom-iszkémia drámaian megváltoztatja az energiametabolizmust. Az iszkémia azt jelenti, hogy az elégtelen koronária-vérátáramlás miatt nem jut elegendő oxigén a szénhidrátok elégetéséhez és az ATP megfelelő sebességű újratermelődéséhez. A koronáriakeringés részleges károsodása (a normál 30-60\%a) esetén az oxigénfelhasználás és az ATP-termelés arányosan csökken, míg a szív glükózfelvétele nő. A normál aerob viszonyoktól eltérően, iszkémia esetén a szívizom által felvett glükóz a mitokondriumokban nem tud teljes mértékben oxidálódni, hanem tejsavvá alakul, és így a szív átkapcsol a normál „tejsavfelvevő üzemmódról" tejsavtermelésre. Mindez a szívizomsejtek homeosztázisának drámai felborulásához vezet: az ATP-szint csökken, laktát és $+\mathrm{H}$-ion halmozódik fel, az intracelluláris pH csökken, a kontrakciók ereje mérséklődik. Az iszkémiás szövet - a nagy mennyiségű laktáttermelés ellenére - elsősorban a zsírsavak oxidációja révén (50-70\%) igyekszik kellő energiát biztosítani. A szív anyagcseréjének ilyen irányú, iszkémia indukálta károsodását hivatott csökkenteni a trimetazidin, amely a zsírsavak oxidációjának csökkentése, valamint a glükóz és a laktát elégetésének növelése révén javítja az iszkémiás szívbetegek klinikai állapotát (4).

\section{Pozitron emissziós tomográfia a szívizom-anyagcsere vizsgálatára}

A pozitron emissziós tomográfia (PET) noninvazív módon nyújt kiváló lehetőséget a humán patofiziológiai folyamatok tanulmányozására. Dinamikus ${ }^{11} \mathrm{C}$-acetát-PET-vizsgálattal egyszerre becsülhető fel a szívizom

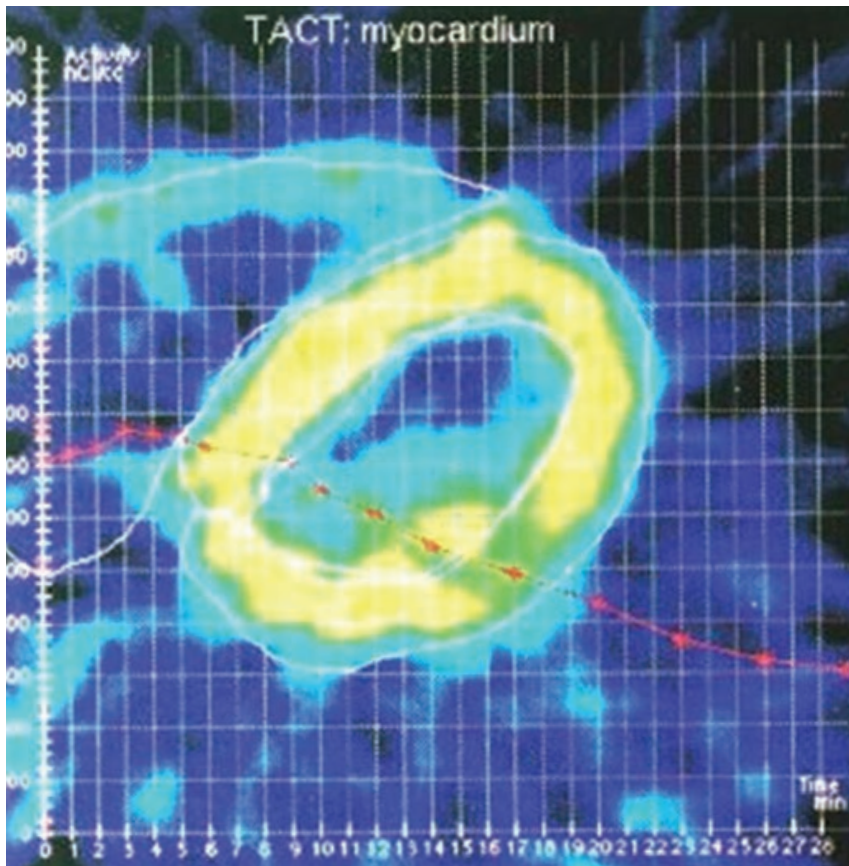

1. ábra. Dinamikus szívizom oxidatív anyagcsere-vizsgálat ${ }^{11} \mathrm{C}$-acetáttal. A bal kamrai myocardium felett vizsgált aktivitás kimosódási görbéjének (piros vonal) első szakasza az $\mathrm{O}_{2}$-felhasználást jellemzi. Monoexponenciális illesztéssel határozható meg a kimosási görbe időállandója (K-mono), amely a regionális $\mathrm{O}_{2}$-fogyasztással arányos

regionális perfúziója és oxidatív metabolizmusa. A szívizom teljes oxidatív anyagcseréjét ${ }^{11} \mathrm{C}$-acetáttal azért lehet mérni, mert az acetát az oxidáció végső közös útján a Szent-Györgyi-Krebs-ciklusban ég el, így a kimosódási görbe első komponense az $\mathrm{O}_{2}$-felhasználást jellemzi. Monoexponenciális illesztéssel határozható meg a kimosási görbe időállandója (K-mono), amely a regionális $\mathrm{O}_{2}$-fogyasztással arányos (1. ábra) (5).

A szív anyagcseréjének vizsgálatára a fenti - inkább kutatási területeken alkalmazott jelzőanyagokon kívül - klinikailag a szívizom életképességének a vizsgálatára arany standardként a glükóz analóg ${ }^{18} \mathrm{~F}$-fluoro-dezoxi-glükózt ( $\left.{ }^{18} \mathrm{FDG}\right) \mathrm{PET}$ jelzőanyagot ismerik el, amely a viabilis szívizomsejtek jelölésével jól elkülöníti a heges és a károsodott vérellátás miatt rosszul öszszehúzódó „alvó” (hibernált) - még megmenthető - szívizmot, ezáltal előre jelezhető a revaszkularizációs beavatkozás eredményessége (6-8).

A glükózfelvételt jelző ${ }^{18}$ FDG a glükózhoz hasonlóan jut a miokardiális sejtekbe, de ott foszforilálódást követően nem metabolizálódik tovább, hanem ${ }^{18}$ FDG-6-foszfát formájában akkumulálódik. Dinamikus vizsgálati körülmények között a Patlak-analízis alapján kvantifikálható az eredő foszforiláció. Az aktuális vércukorszint ismeretében kiszámítható a regionális miokardiális glükózfelvétel mmol/min/szívizomszövet (g) mértékegységben (2. ábra). Láthatjuk, hogy a szívizom bizonyos szempontból „mindenevő": a szubsztrát-környezettől függően egyaránt képes hasznosítani szénhidrátot vagy zsírsavakat, de 

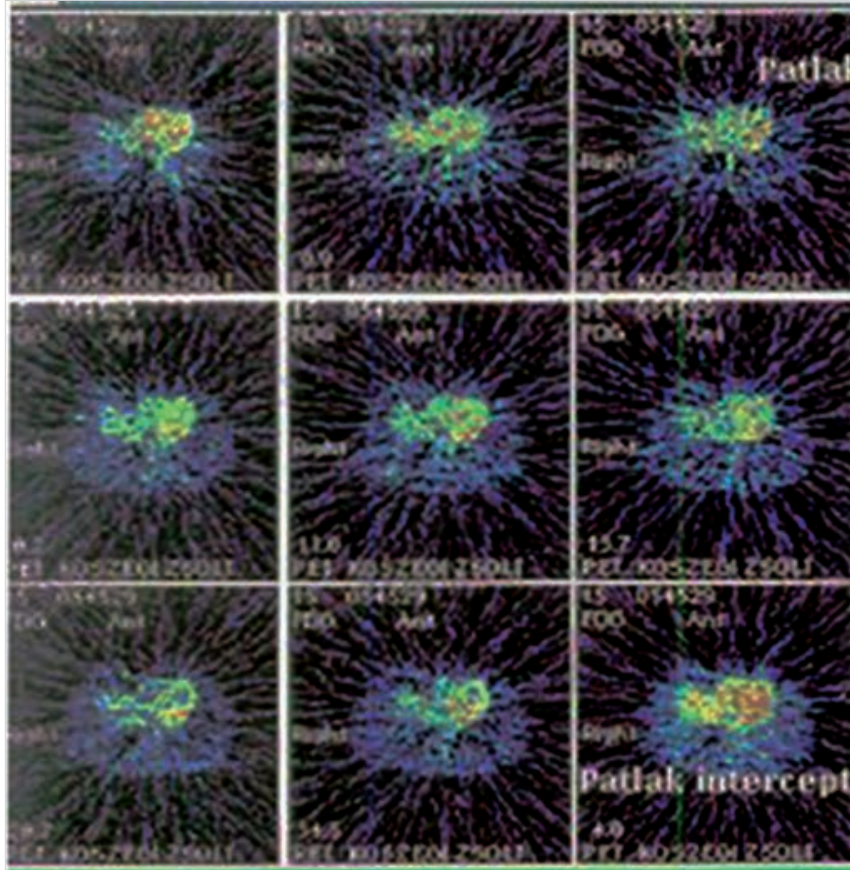

\section{3}

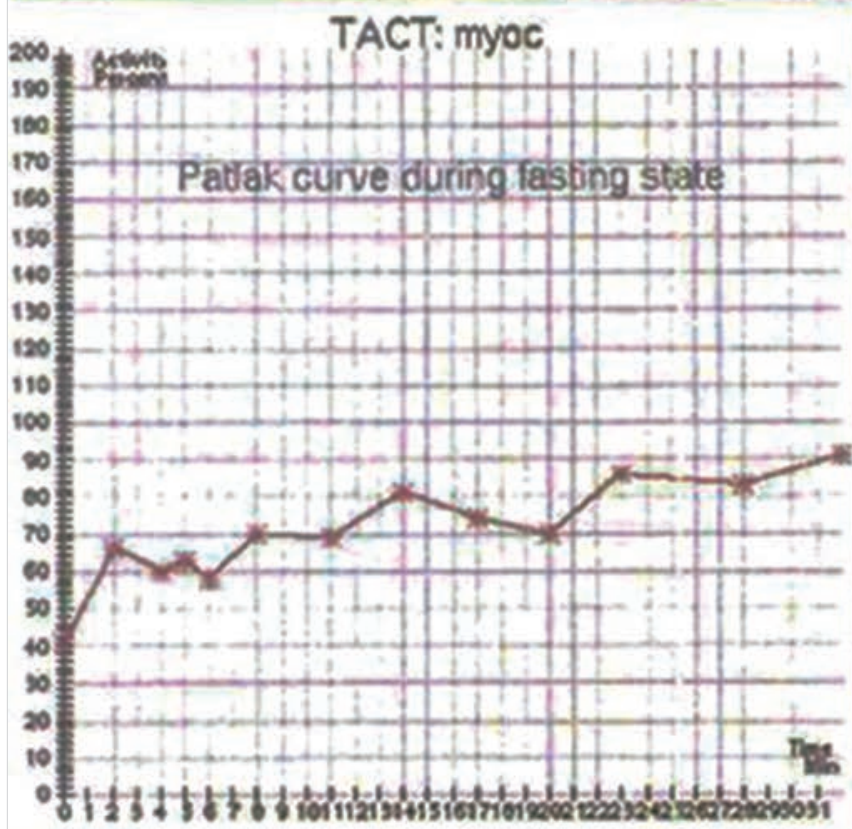

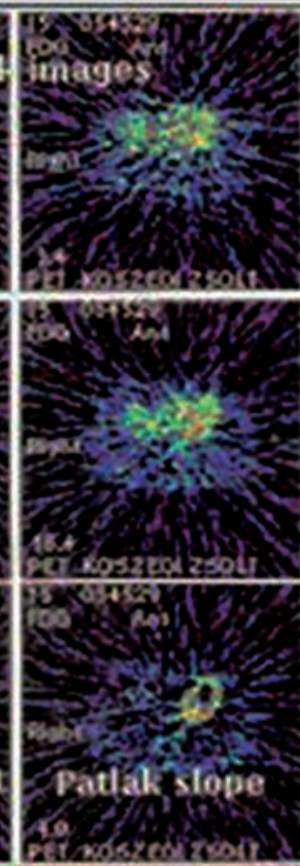
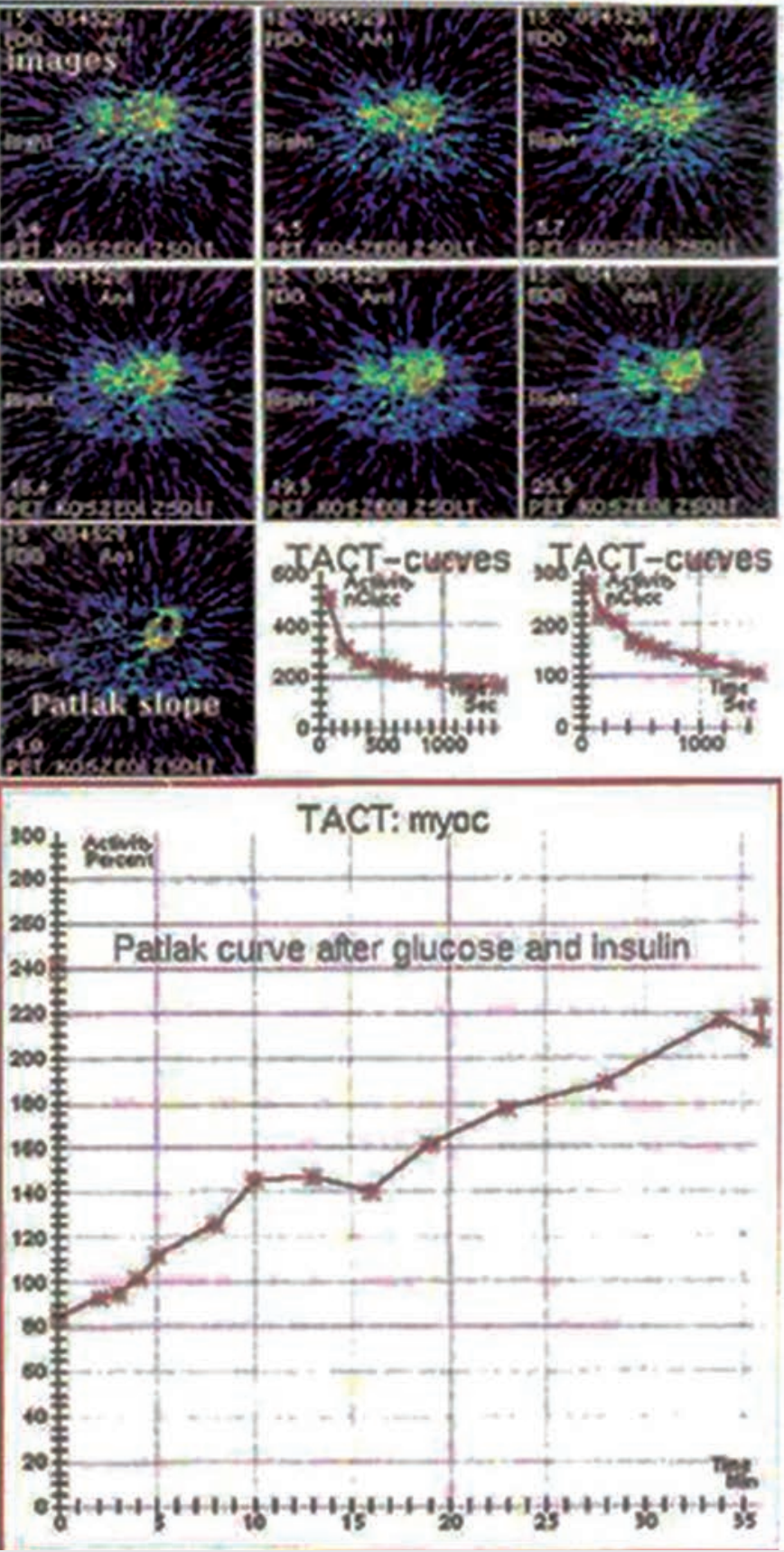

2. ÁBRA. Dinamikus ${ }^{18} \mathrm{FDG}$-vizsgálat. A felső négyzetekben a mellkas horizontális metszeteiben követhető a jelzőanyag útja a jobb kamrai vér poolból a kisvérköri keringést követően a bal kamra üregébe, majd a szívizomba. Az ún. Patlak-analízis alapján a bal kamrai „bemenő jel” és a szívizom feletti „szöveti válasz” viszonya alapján kvantifikálható a regionális miokardiális glükózfelvétel. Az alsó két diagram mutatja, hogy glükóz és inzulin intravénás adását követően a Patlak-görbe meredeksége kb. háromszorosára nő a szívizom glükózfelvételének fokozódásával arányosan. (A PET-felvétel 1996-ban Uppsalában történt, a vizsgálati alany jelen közlemény szerzője volt.)

az egységnyi oxigénfelhasználásra jutó energiatermelés nem azonos a különböző tápagyagok elégetése során. $6 \mathrm{O}_{2}$-molekula szükséges egy szölöcukor-molekula teljes elégetéséhez, ami 31 ATP-t termel. Ugyanakkor egy palmitinsav molekula elégetése $23 \mathrm{O}_{2}$-molekula felhasználásával lehetséges, ami viszont csak 105 ATP-t produkál. Így a glükózoxidáció során egy $\mathrm{O}_{2}$-molekulára átlagosan 5,2 ATP-képződés esik, míg zsírsavoxidá- cióval egy $\mathrm{O}_{2}$ csak 4,6 ATP termelődését eredményezi. Egyéb mechanimusok belépésével a (pl. a triacilglicerol kör fokozódása útján) a glükózoxidáció akár 33\%-kal több energiát is biztosíthat a szívizomnak, mint a zsírsavoxidáció. Ez a biokémiai sajátosság adott alkalmat arra, hogy a farmakológiai kezelés célpontjába kerüljön a zsírsavoxidáció gátlása, illetve a glükózoxidáció fokozása $(9,10)$. 

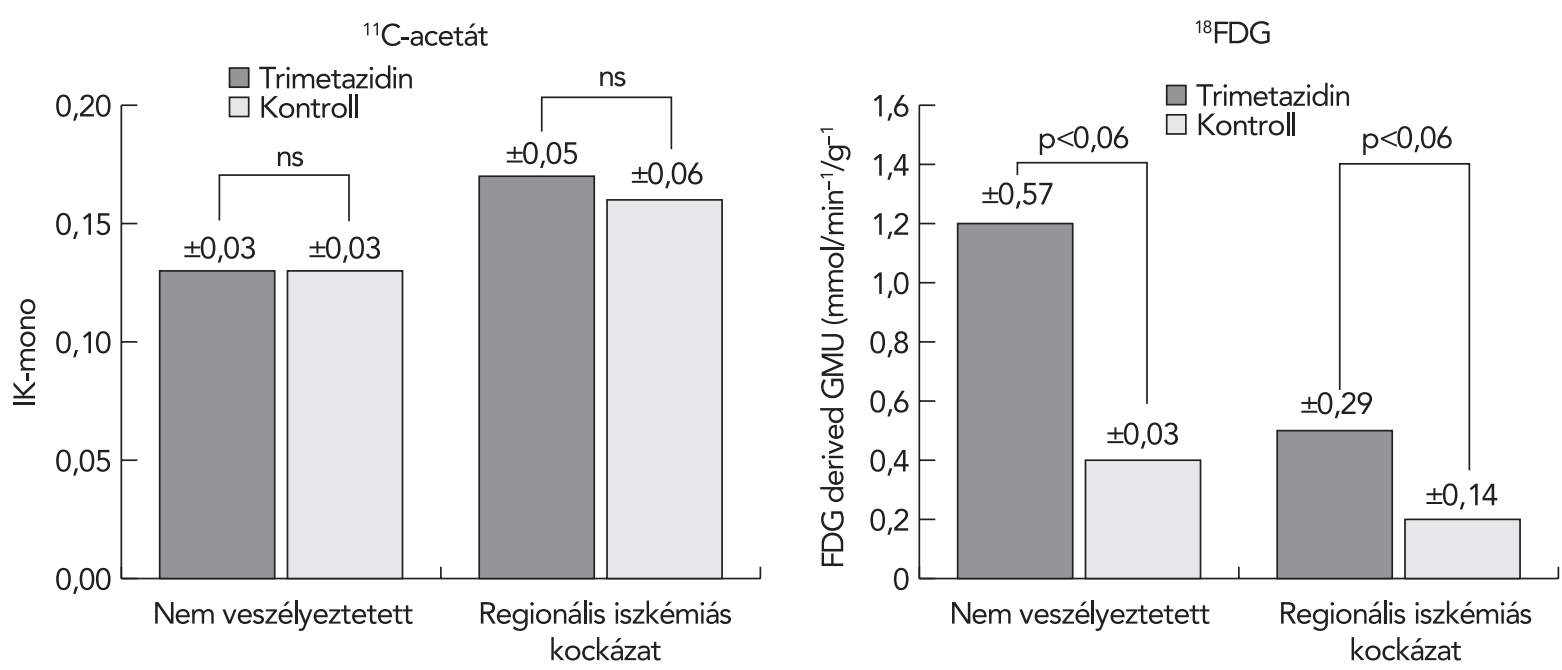

3. ÁBRA. Állatkísérletben a bal elülső leszálló koszorúérág elkötésével idéztek elő iszkémiát a bal kamra elülső falában. A szívizom teljes oxidatív anyagcserét acetáttal (bal oldali panel), a regionális glükózfelvételt FDG-vel (jobb oldali panel) vizsgálták úgy, hogy az állatok egy része trimetazidin előkezelésben részesült. Mind az iszkémiás mind a normál szívizomban fokozott glükózfelvételt észleltek a kezelés hatására. Mivel a teljes oxidatív metabolizmust jelző acetátfelvétel nem változott szignifikánsan, ezért arra következtettek, hogy a glükózoxidáció fokozódása a zsírsavoxidáció gátlása útján jött létre.

\section{A trimetazidin hatásmechanizmusa}

A trimetazidin (1-[(2,3,4-trimetoxifenil)metil]piperazin) (TMZ) hatékonynak bizonyult a szívizom-anyagcsere kedvező befolyásolására. Mody és munkatársai 1998ban PET experimentális vizsgálatokkal igazolták, hogy a TMZ hemodinamikai hatás nélkül mind az iszkémiás mind a normál szívizom-anyagcseréjét a zsírsavoxidáció felöl az energetikailag hatékonyabb glükózoxidáció felé tereli (4) (3. ábra).

2000-ben Kantor és munkatársai leírták a TMZ pontos támadáspontját: kimutatták, hogy a gyógyszer a 3-ketoacil-CoA-tioláz hosszú láncú izoformját gátolja, amely enzim a mitokondriális zsírsavoxidációban játszik döntő szerepet. A zsírsavak oxidációjának gátlásával a TMZ szignifikáns mértékben növeli a glükózoxidáció sebességét meghatározó enzimnek, a piruvát-dehidrogenáz- nak az aktivitását, így az egységnyi oxigénfogyasztásra eső munkát (9).

A további klinikai tanulmányok is igazolták, hogy a TMZ optimalizálja a szívizom energiafelhasználását, és ezzel a kardiovaszkuláris megbetegedések kezelésének új fejezetét nyitotta a krónikus iszkémiás szívbetegség kezelésére (11-17).

\section{A trimetazidin klinikai alkalmazása perkután koronária-intervenciót igénylő betegeknél}

A fent említett vizsgálatokban az effort angia pectoris kezelésének hatékonyságát az anginás panaszok és a terheléses EKG-n kialakuló eltérések csökkenésével mérték fel revaszkularizáción átesett betegekben is.
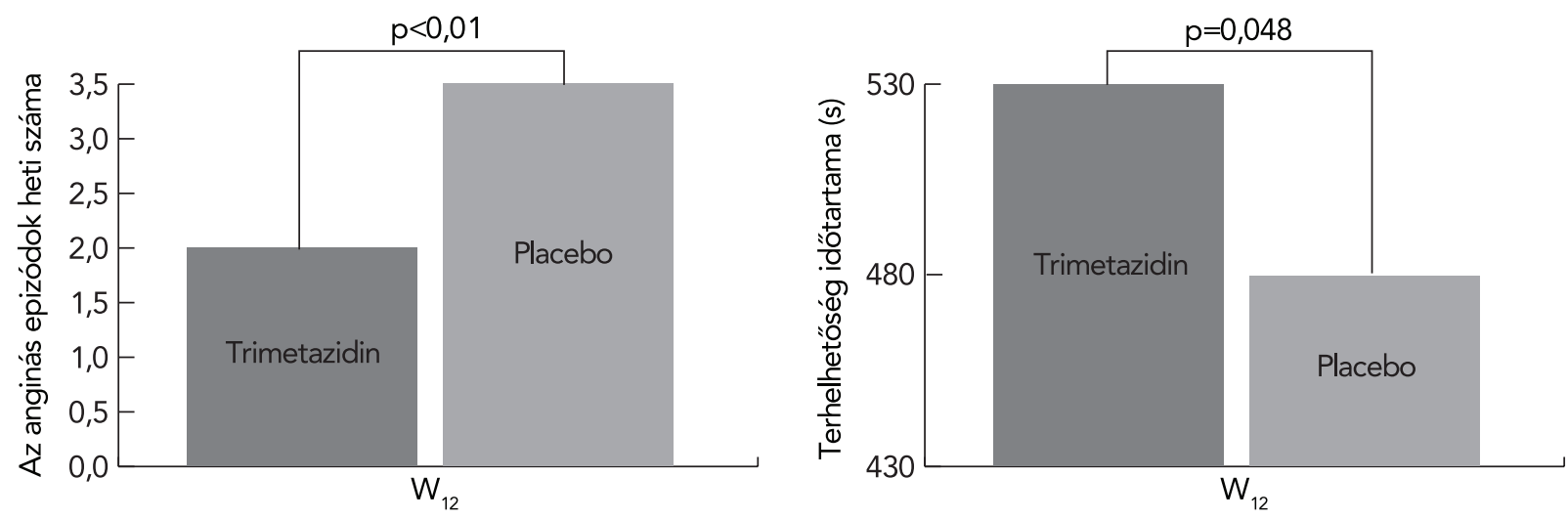

4. ÁBRA. A TRIMPOL II-vizsgálat revaszkularizált alcsoportjának analízise: 12 hetes trimetazidin kezelés hatása az epizódok heti előfordulására (bal oldali panel) és a terheléses EKG alatt az $1 \mathrm{~mm}$-es ST-depresszió megjelenéséig eltelt időre (jobb oldali panel) 


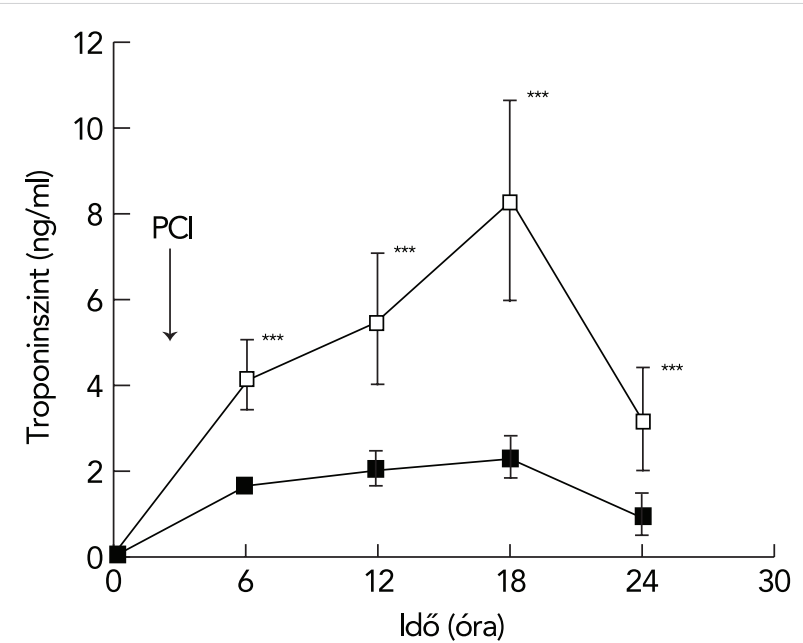

5. ÁBRA. A troponinszintek alakulása a TMZ-csoportban (fekete négyzet) és a placebocsoportban (fehér négyzet)

W. Ruzyllo és munkatársai a TRIMetazidine in POLand (TRRIMPOL II) study azon alcsoportját (94 beteg) analizálták, akiknél a napi 100 mg atenolol adása mellett a tünetek továbbra is perzisztáltak bypass-mútét vagy perkután koronária-intervenció (PCI) után. 12 hetes TMZ-kezelés szignifikánsan csökkentette az anginás epizódok heti előfordulási számát, és jelentősen emelte a terheléses EKG alatt az 1 mm-es ST-depresszió megjelenéséig eltelt időt (385 másodpercről 465-re [p $<0,01])$ (17) (4. ábra).

Újabban lyengar és Rosano a TMZ prognosztikai elönyét is bizonyította. A METRO (ManagEment of angina: a reTRospective cOhort) studyban 353 szívizominfarktus szenvedett betegnél átlagosan 27,2 hónap követési idő alatt a túlélési esély szignifikánsan javult a TMZ hatására (a halálozási esélyarány 0,36 volt) (14).

Viszonylag nagy betegszámú vizsgálatok adatai állnak rendelkezésre a TMZ koszorúér-intervenció alatti citoprotektív hatásáról. A közvetlenül sejtszinten ható ked- vező metabolikus hatás kivédheti az intervencióval járó átmeneti iszkémia okozta miokardiális károsodást, és csökkentheti a reperfúziós károsodás mértékét is (18). A LIST-vizsgálatban (Limitation of Infarct Size by Trimetazidine Trial) akut miokardiális infarktus primer PCl-kezelése során folyamatos ST-szakasz monitorozással elemezték az intervenció előtt elkezdett 48 órás intravénás TMZ-infúzió hatását. Azt találták, hogy a placebo infúzióhoz képest az ST-eleváció nagyobb mértékben és gyorsabban csökkent (19).

Bonello és munkatársai (20) azt figyelték meg, hogy a $\mathrm{PCl}$ előtti per os $\mathrm{TMZ}$ előkezelés a posztprocedurális troponinszintet szignifikánsan csökkentette (5. ábra). Eredményeikből arra következtettek, hogy a TMZ csökkenti az iszkémiás-reperfúziós károsodást. Az experimentális vizsgálatok adatainak extrapolálásával a szerzők a kardioprotektív hatás hátterében a TMZ mitokondriális hatását is feltételezték, miszerint a TMZ gátolhatja a mitokondriumok sejtpusztuláshoz vezető kóros permeabilitás-fokozódását.

2014-ben az International Journal of Cardiology-ban jelent meg Chen és munkatársai cikke a gyógyszerkibocsátó (drug eluting stent: DES) stentbeültetést követő TMZ-kezelés hatásáról. 768 beteget vontak be, közülük 384-et randomizáltak a TMZ-kezelésbe, míg a kontrollcsoportba kerülő 384 beteg TMZ-t nem tartalmazó standard kezelést kapott (21). A DES-beültetést követően 9-13 hónappal minden betegnél elvégezték a szívkatéteres utánkövetést is, és azt találták, hogy a stentelt szegmentumban 50\%-os átmérőcsökkenést meghaladó restenosis szignifikánsan kevesebb esetben mutatkozott a TMZ-csoportban, mint kontrollesetekben $(4,2 \%$ vs. $11,1 \%$, $p=0,001)$ (6. ábra). Elsősorban ennek köszönhetően a major adverz kardiovaszkuláris események száma is jelentősen csökkent a TMZ-t szedő betegeknél (6,1\% vs. $10,8 \%, p=0,032)$. A többváltozós regressziós logisztikus analízis azt mutatta, hogy a TMZ ha-
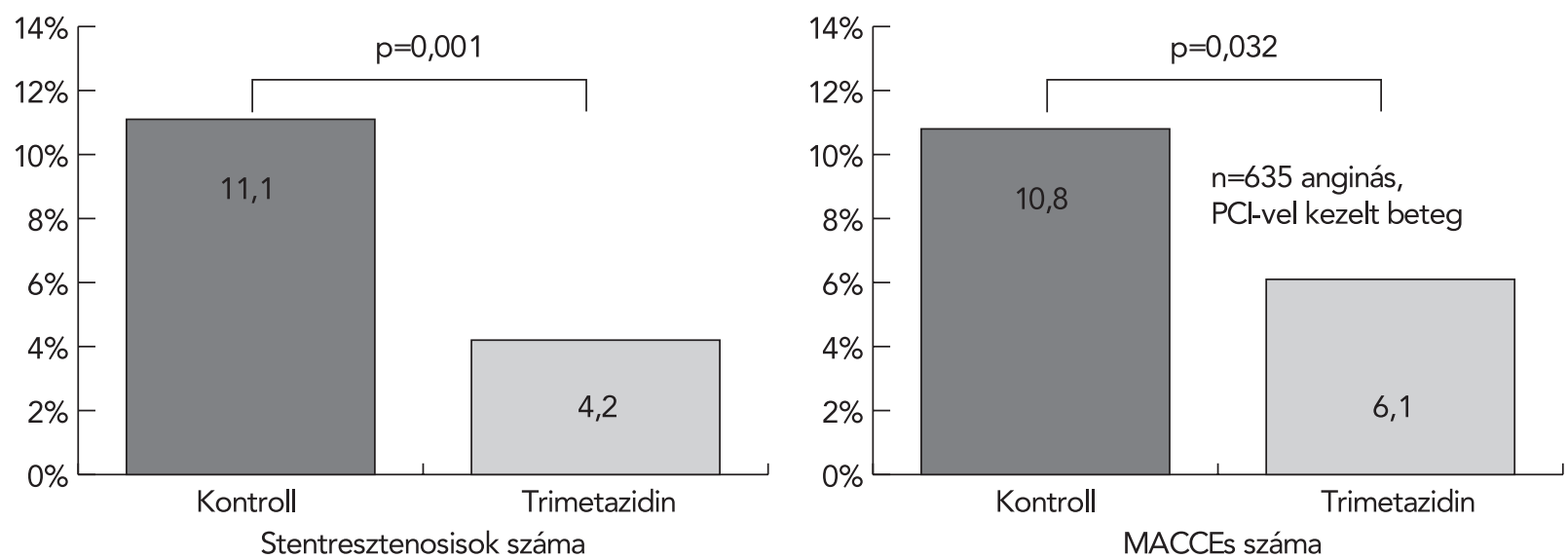

6. ÁBRA. A TMZ hatása az instent-restenosis kialakulására (bal oldali panel) és a súlyos nemkívánatos kardiális vagy cerebrovaszkuláris események előfordulására az 1 éves követési idő alatt (MACCE: Major Adverse Cardiac and Cerebrovascular Event) (jobb oldali panel) 
tékonyan csökkentette az instent restenosis arányát (esélyhányados 0,376; $p=0,003$ ).

Az eredmények magyarázataként a szerzők felvetik, hogy a TMZ a DES beültetését követően a (neo)endothelre gyakorolt kedvező metabolikus hatása folytán csökkentheti a kóros mértékű intimaproliferáció kialakulását. Feltételezésüket azokra a korábbi közleményekre alapozzák, amelyekben egyrészt kimutatták, hogy a TMZ hatékonyan serkentette a carotis ballontágítást követő érfalsérülés reendothelizációját (22), másrészt humán vizsgálatban a radialis katéterezést követően demonstrálták az endothelfunkciót javító hatását (23).

Ha ezek az előzetes eredmények további nagy esetszámú randomizált vizsgálatban is megerősítést nyernek, úgy várhatóan, az ISZB terápiás arzenáljában a stentimplantáció utáni esetekben még nagyobb szerepet kaphat a TMZ.

\section{Irodalom}

1. Grover-McKay M, Schelbert $H$, Schwaiger $M$, et al. Identification of impaired metabolic reserve by atrial pacing in patients with significant coronary artery stenosis. Circulation 1986; 74: 281-292. DOI: 10.1161/01.CIR.74.2.281

2. Gropler R, Siegel B, Sampathkumaran K, et al. Dependence of recovery of contractile function on maintenance of oxidative metabolism after myocardial infarction. J Am Coll Cardiol 1992; 19: 989-997. 3. Tillisch J, Brunken R, Marshall R, et al. Reversibility of cardiac wall motion abnormalities predicted by positron emission tomography. N Engl J Med 1986; 314: 884 DOI: 10.1056/NEJM198604033141405 4. Mody FV, Singh BN, Mohiuddin IH, et al. Trimetazidine-induced enhancement of myocardial glucose utilization in normal and ischemic myocardial tissue: an evaluation by positron emission tomography. Am J Cardiol 1998; 82(5A): 42K-49K. DOI: 10.1016 S0002-9149(98)00536-0

5. Hata T, Nohara R, Fujita M, et al. Noninvasive assessment of myocardial viability by positron emission tomography with $11 \mathrm{C}$ acetate in patients with old myocardial infarction. Usefulness of low-dose dobutamine infusion. Circulation 1996; 94(8): 1834-41. DO, 10.1161/01.CIR.94.8.1834

6. Kertész A, Kőszegi Zs, Fülöp T, et al. Dinamikus18FDG-PET vizsgálat a szívizom glükózfelvételének mérésére. Cardiológia Hungarica 1998 (Suppl 1): 26.

7. Kőszegi Zs, Szakáll Sz, Trón L, et al. Nagy kockázatú koszorúér bypass-mủtét eredményességének előrejelzése pozitron emissziós tomográfiával. Orvosi Hetilap 1997; 138: 1691-1693.

8. Kőszegi Zs, Szűk T, Voith L, et al. Metabolic and contractile reserve of infarcted myocardium in relation to collateralization. Journal of Nuclear Cardiology 1997; 4: S81.

9. Kantor PF, Lucien A, Kozak R, et al. The antianginal drug trimeta- zidine shifts cardiac energy metabolism from fatty acid oxidation to glucose oxidation by inhibiting mitochondrial long-chain 3-ketoacyl coenzyme A thiolase. Circ Res 2000; 86(5): 580-8. DOl: 10.1161/01. RES.86.5.580

10. Lopaschuk GD, Ussher JR, Folmes CD, et al. Myocardial fatty acid metabolism in health and disease Physiol Rev 2010; 90: 207-258. DOI: 10.1152/physrev.00015.2009

11. Rónaszéki A. Trimetazidin terápia - Kinek? Mikor? Card Hung 2013; 43: 90-93.

12. Zámolyi K. A trimetazidin kedvező hatása revaszkularizáció során. Cardiologia Hungarica 2007; 37: D1.

13. Dézsi CA. Trimetazidine in Practice: Review of the Clinical and Experimental Evidence. Am J Ther 2016; 23(3): e871-9. DO 10.1097/MJT.0000000000000180

14. Iyengar SS, Rosano GMC. Effect of Antianginal Drugs in Stable Angina on Predicted Mortality Risk after Surviving a Myocardial Infarction. A Preliminary Study (METRO). American Journal of Cardiovascular Drugs 2009; 9(5): 293-7. DOI: 10.2165/11316840000000000-00000

15. Fi Zs, Kovács G, Szentes V. A trimetazidin szerepe a diabeteses microangiopathia kezelésében ischaemiás szívbetegség esetén. Orv Hetil 2015; 156(19): 760-763. DOl: 10.1556/650.2015.30160 16. Fi Zs, Kovács G, Szentes V. A trimetazidin helye az iszkémiás szívbetegség kezelésében. Orvostovábbképző Szemle 2015; 22(2): 34-41. 17. Ruzyllo W, Szwed H, Sadowski Z, et al. Efficacy of trimetazidine in patients with recurrent angina: a subgroup analysis of the TRIMPOL II study. Curr Med Res Opin 2004; 20(9): 1447-54. DOI: 10.1185/030079904X2637

18. Chen YD, Zhao LK, Tian F, et al. Evaluation of the myocardial protection of trimetazidine during percutaneous coronary intervention: a multi-center randomized and controlled clinical study. Chin J Intern Med 2010; 49 (6): 473-6. DOl. 10.3760/cma.j.is sn.0578-1426.2010.06.006

19. Steg PG, Grollier G, Gallay P, et al. LIST Study Group. A randomized double-blind trial of intravenous trimetazidine as adjunctive therapy to primary angioplasty for acute myocardial infarction. Int J Cardiol 2001; 77(2-3): 263-73.

20. Bonello L, Sbragia P, Amabile N, et al. Protective effect of an acute oral loading dose of trimetazidine on myocardial injury following percutaneous coronary intervention. Heart 2007; 93(6): 7037. DOI: 10.1136/hrt.2006.107524

21. Chen J, Zhou S, Jin J, et al. Chronic treatment with trimetazidine after discharge reduces the incidence of restenosis in patients who received coronary stent implantation: A 1-year prospective follow-up study. Int J Cardiol 2014; 174(3): 634-9. DOI: 10.1016/j.i] card.2014.04.168

22. Yoon JW, Cho BJ, Park HS, et al. Differential effects of trimetazidine on vascular smooth muscle cell and endothelial cell in response to carotid artery balloon injury in diabetic rats. Int J Cardiol 2013; 167(1): 126-33. DOI: 10.1016/j.ijcard.2011.12.061

23. Park KH, Park WJ, Kim MK, et al. Effects of trimetazidine on endothelial dysfunction after sheath injury of radial artery. Am J Cardiol 2010; 105: 1723-7. DOI: 10.1016/j.amjcard.2010.01.351 